4 Yang HYT, Erdos EG, Levin Y. A dipeptidyl carboxypeptidase that converts angiotensin I and inactivates bradykinin. Biochim Biophys Acta 1971;214:374-6.

5 Kiowski W, van Brummelin P, Hulthen L, Amman FW, Bukler FR. Antihypertensive and renal effects of captopril in relation to renin activity and bradykinin-induced vasodilation. Clin Pharmacol Ther 1982;31:677-84.

(Accepted 19 September 1986)

Medicines Division, Market Towers, Department of Health and Social Security, London SW8 5NQ

SUSAN M WOOD, BSC, MD, senior medical officer

RONALD D MANN, MD, MRCP, principal medical officer

Wolfson Unit of Clinical Pharmacology, The University, Newcastle upon Tyne NE1 7RU

MICHAEL D RAWLINS, MD, FRCP, professor

Correspondence to: Dr Wood.

\section{Dihydroxypropoxymethyl guanine in the treatment of AIDS related retinitis due to cytomegalovirus}

Retinal changes in patients with the acquired immune deficiency syndrome (AIDS) have frequently been described recently. The changes include cotton wool spots, superficial and deep retinal haemorrhages, perivasculitis, and a type of retinitis presumed to be caused by cytomegalovirus..$^{1-3}$

In our experience five out of seven eyes have progressed unremittingly to complete blindness, and until recently no effective treatment had been found for this disease. The nucleoside 9-(1, 3 dihydroxy 2-propoxymethyl) guanine is being investigated as a possible treatment. Our cases confirm the findings of Palestine $e t a l^{4}$ that this drug is effective in treating retinitis caused by cytomegalovirus but that recurrence is likely after a single course of the drug.

\section{Case reports}

Case 1-A 54 year old homosexual man with AIDS and cytomegalovirus myelopathy complained of left sided temporal field loss. His reading vision was N5 in both eyes, and a patch of nasal retinitis was seen. Sixteen days later he had no perception of light in the left eye, and the entire retina was inflamed. The right eye remained normal. He was readmitted two weeks later after noticing visual field loss in the right eye. He received treatment with dihydroxypropoxymethyl guanine $350 \mathrm{mg}$ twice daily for two weeks, and during this time vision in the right eye remained $6 / 9$ and N6. One week after the course of treatment the retinitis became active, and within two weeks the vision was lost and he had no perception of light in either eye. He died three weeks later.

Case 2-A 31 year old homosexual man with AIDS related complex presented with bilateral follicular conjunctivitis. He had 6/9 vision in both eyes. Fundoscopy showed a large area of peripheral retinal necrosis with a surrounding fluffy white border of retinitis in the upper temporal retina of the left eye. A presumptive diagnosis of retinitis due to cytomegalovirus was made. Two weeks later he still had 6/9 vision in both eyes, but he had an increased peripheral field defect and increased retinitis. He was admitted to hospital and received a two week course of dihydroxypropoxymethyl guanine $350 \mathrm{mg}$ twice daily. During this period the area of retinitis remained static, but three weeks after he was discharged from hospital the vision in the left eye had deteriorated to registering only hand movements and the area of retinitis in the left eye had extended to the posterior pole (figure). There were disc haemorrhages, and the macula was oedematous. At this time a small patch of retinitis was noticed in the right eye. He received a further two week course of dihydroxypropoxymethyl guanine and then treatment with a maintenance dose five days a week. The retinitis in both eyes steadily improved (figure), and at the time of writing the visual acuity was $6 / 6$ in the right eye and had improved in the left from registering only hand movements to $6 / 12$.

\section{Comment}

Cytomegalovirus is a deoxyribonucleic acid (DNA) virus of the herpes group, which causes a distinctive "owl's eye" cytopathogenic effect. It has been shown to cause destructive retinitis in immunosuppressed patients, most frequently patients with renal allografts. The immune response to cytomegalovirus is directed against the immediate early phase viral protein products and is mediated by $\mathrm{T}$ cells and natural killer cells. ${ }^{5}$ The nucleoside dihydroxypropoxymethyl guanine acts by inhibiting DNA polymerase in a way similar to acyclovir.

In patients with renal allografts retinitis responds to a reduction in immunosuppressant drugs. In our patients we have seen a good biological effect of the drug dihydroxypropoxymethyl guanine on retinitis thought to be caused by cytomegalovirus. In both cases withdrawal of the drug led to a rapid recurrence of the disease. Dihydroxypropoxymethyl guanine seems to
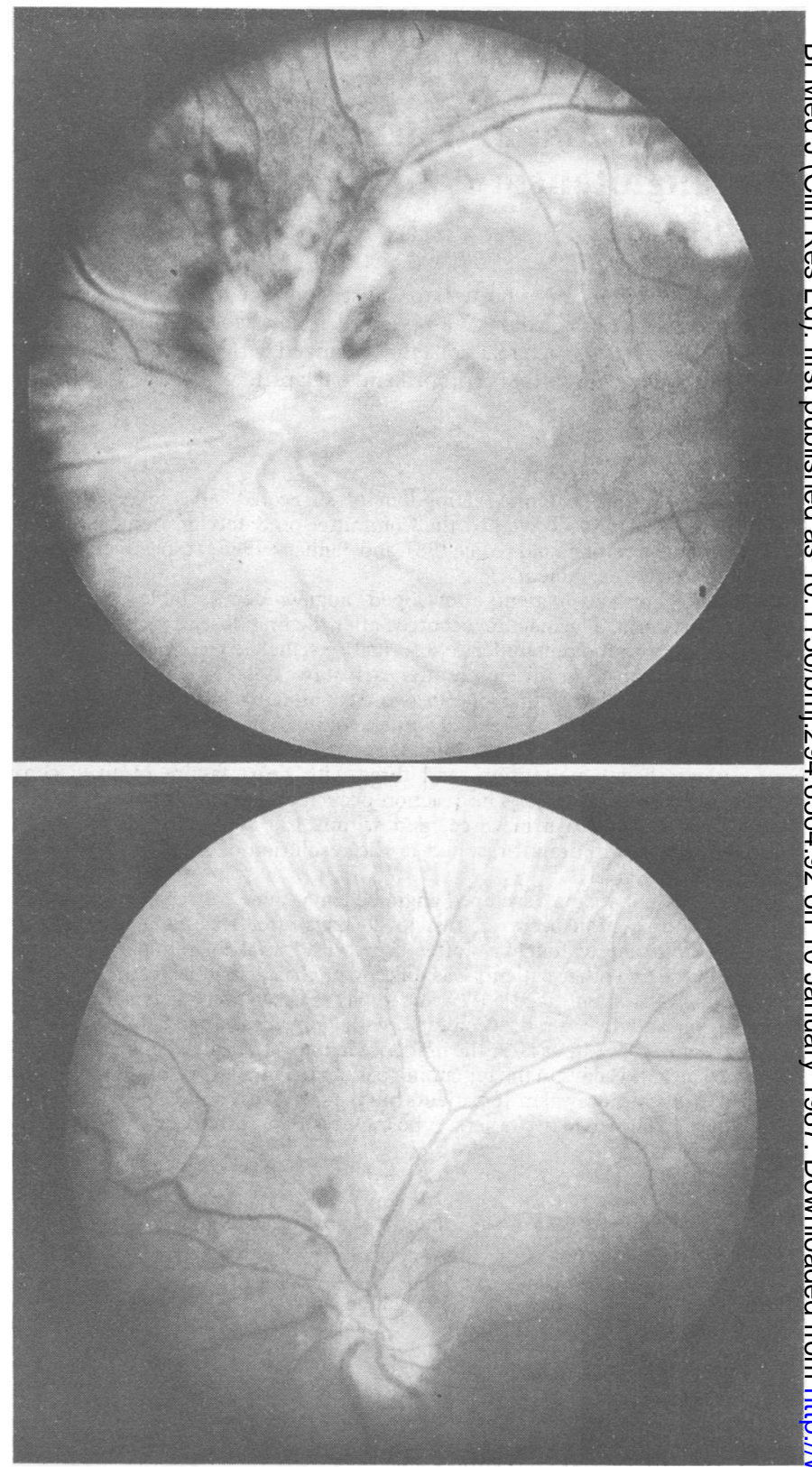

Case 2: active retinitis in left eye (above), and left eye after treatment with dihydroxypropoxymethyl guanine (below).

prevent deterioration of AIDS related retinitis but is effective only if given indefinitely and does not represent a cure. The myelotoxic effect of the drug given at a maintenance dose of $5 \mathrm{mg} / \mathrm{kg}$ daily is the main limiting factor of its long term efficacy as retinitis usually recurs when the drug is withdrawn.

We thank Syntex Corporation for supplying the dihydroxypropoxymethyl guanine; Dr D J Jeffries, Department of Virology, St Mary's Hospital, D Paddington, for help and encouragement; and Dr B Gazzard and Dr A Lawrence, St Stephen's Hospital, Chelsea, for permission to report these cases.

1 Khadem M, Kalish SB, Goldsmith J, et al. Ophthalmologic findings in AIDS. Arch Ophthalmok 1984;102:201.

2 Kestelyn P, Van de Perre $P$, Rouvroy D, etal. A prospective study of the ophthalmologic findings in AIDS in Africa. Am J Ophehalmol 1985;100:230-8.

Friedman AH, Orellana J, Freeman WR, et al. Cytomegalovirus retinitis: a manifestation of AIDS Br f Ophthalmol 1983;67:372-80.

4 Palestine AG, Stevens G Jr, Lane HC, et al. Treatment of CMV retinitis with dihydroxy propoxymethyl guanine. Am $\mathcal{f}$ Ophthalmol 1986;101:95-101.

5 Sissons JGP. The immunology of CMV infection. I R Coll Physicians Lond 1986;20:40-4.

(Accepted 30 October 1986)

St Stephen's Hospital, London SW10 9TH

M L HARRIS, MB, BS, ophthalmic registrar

M B R MATHALONE, FRCS, DO, consultant ophthalmologist

Correspondence to: Dr Harris. 